\title{
Inhibition of the SK-N-MC human neuroblastoma cell line in vivo and in vitro by a novel nutrient mixture
}

\author{
M. WAHEED ROOMI, TATIANA KALINOVSKY, NUSRATH W. ROOMI, \\ ALEKSANDRA NIEDZWIECKI and MATTHIAS RATH \\ Dr Rath Research Institute, Oncology Division, Santa Clara, CA, USA
}

Received November 26, 2012; Accepted January 29, 2013

DOI: 10.3892/or.2013.2307

\begin{abstract}
Neuroblastoma, a peripheral nervous system cancer that can be highly invasive and metastatic, accounts for $8-10 \%$ of all solid childhood tumors in children under the age of 15 years. Despite multiple clinical efforts, prognosis remains poor for this enigmatic disease. A nutrient mixture (NM) containing lysine, proline, ascorbic acid and green tea extract has shown significant antitumor effects. Using the nude mouse xenograft model, we investigated the efficacy of NM. We also tested the effect of NM in vitro, evaluating cell viability, secretion of the matrix metalloproteinases (MMP)-2 and MMP-9, tissue inhibitor of metalloproteinase (TIMP)-2 secretion, Matrigel invasion and cellular apoptosis and morphology. Athymic nude mice 5-6 weeks of age were inoculated with $3 \times 10^{6}$ SK-N-MC neuroblastoma cells subcutaneously and randomly divided into two groups. Group A was fed a regular diet and group B a regular diet supplemented with $0.5 \%$ NM. Four weeks later, the mice were sacrificed and their tumors were excised, weighed and processed for histology. We also tested the effect of NM in vitro. NM inhibited the growth of xenograft tumors by $22 \%(\mathrm{P}=0.04)$; and, in vitro, $\mathrm{NM}$ induced dose-dependent inhibition of cell proliferation with a decrease of $27 \%(\mathrm{P}=0.001)$ and $36 \%(\mathrm{P}=0.002)$ at 500 and $1000 \mu \mathrm{g} / \mathrm{ml} \mathrm{NM}$ compared to the control, respectively. Zymography revealed MMP-2 secretion in normal cells and PMA (100 ng/ml)-induced MMP-9 secretion. NM inhibited the secretion of both MMPs with total blockage at a concentration of $100 \mu \mathrm{g} / \mathrm{ml}$. Reverse zymography demonstrated a dose-dependent increase in TIMP-2 expression by NM. Notable, SK-N-MC human neuroblastoma cells were not invasive through Matrigel. NM induced dose-dependent apoptosis of SK-N-MC cells. The results suggest that NM may have therapeutic potential in treating neuroblastoma.
\end{abstract}

Correspondence to: Dr Aleksandra Niedzwiecki, Dr Rath Research Institute, Oncology Division, 1260 Memorex Drive, Santa Clara, CA 95050, USA

E-mail: author@drrath.com

Key words: neuroblastoma, SK-N-MC, tumor growth, MMP-2, MMP-9, apoptosis

\section{Introduction}

Neuroblastoma, the most common solid extracranial tumor in children, accounts for $7 \%$ of pediatric cancers (1). Approximately 650 new cases of neuroblastoma are diagnosed each year in the United States. The cancer is usually diagnosed at 1 to 2 years of age and $90 \%$ of cases are diagnosed by 5 years of age (1). This embryonal cancer typically arises from the adrenal medulla or paraspinal sympathetic ganglia of the abdomen, chest or neck and often metastasizes to the liver, regional lymph nodes, bone marrow and bone (2). Neuroblastoma tumors that are benign, localized and well differentiated are successfully treated by surgical resection. Still, a majority of neuroblastoma patients develop an aggressive disease that is refractory to intensive therapies. Current treatment for high risk neuroblastoma has reached an extreme toxic and virtually intolerable level that includes intensive chemotherapy, radiotherapy, autologous bone marrow transplantation and retinoid and immunomodulation among others (3). Despite aggressive conventional treatments, the majority of children older than one year of age with advanced stage neuroblastoma die from progressive disease, and only $40 \%$ of children over 4 years of age survive for 5 years, emphasizing an urgent need for the development of innovative effective treatment strategies (4).

Advanced stages of neuroblastoma show increased expression of the matrix metalloproteinase (MMP-2), and a higher MMP-2 to TIMP-2 ratio has been shown to correlate with poorer prognosis for neuroblastoma patients (5). Sugiura et al (6) reported higher levels of MMP-2 and MMP-9 in patients with stage IV (metastatic) disease when compared with those in stages I and II (non-invasive and non-metastatic). MMP-2 was present in both tumor and stromal cells; however, MMP-9 was present in stromal, vascular and perivascular cells surrounding nests of tumor cells.

We have developed strategies to inhibit cancer development and its spread using naturally occurring nutrients such as lysine, proline, ascorbic acid and green tea extract [nutrient mixture (NM)]. This nutrient mixture has exhibited synergistic anticancer activity in vivo and in vitro in a number of cancer cell lines through inhibition of cancer cell growth, MMP secretion, invasion, metastasis and angiogenesis (7-9). Our main objective in this study was to evaluate the effectiveness of NM on neuroblastoma cells in vivo using the nude mouse xenograft model and in vitro, evaluating the effect of NM on 
cell viability, MMP-2 and -9 secretion, TIMP-2 secretion, Matrigel invasion and cellular apoptosis and morphology.

\section{Materials and methods}

\section{In vivo}

Animals. Male athymic mice (NCr-nu/nu), 5 weeks of age on arrival, were purchased from Simonsen Laboratories, Gilroy, CA, USA and maintained in microisolator cages under pathogen-free conditions on a 12-h light/12-h dark schedule for one week. All procedures were performed according to humane and customary care and use of experimental animals and followed a protocol approved by the internal institutional animal safety review committee.

Experimental design. After housing for a week, the mice $(\mathrm{n}=16)$ were inoculated subcutaneously with $3 \times 10^{6}$ neuroblastoma SK-N-MC cells in $0.2 \mathrm{ml}$ PBS and $0.1 \mathrm{ml}$ Matrigel (BD Bioscience, Bedford, MA, USA). After injection, the mice were randomly divided into two groups of 8 mice each; group A mice were fed regular Purina mouse chow and group B the regular diet supplemented with $0.5 \% \mathrm{NM}(\mathrm{w} / \mathrm{w})$. The regular diet was Laboratory Rodent Diet 5001 from Purina Mills, Inc. LLC/TestDiet ${ }^{\circledR}$ (Gray Summit, MO, USA). The 0.5\% NM diet was milled and pressed by Purina Mills and generated by Vita-Tech (Tustin, CA, USA). During the study, the mice consumed, on the average, $4 \mathrm{~g}$ of their respective diets/day. Thus, the supplemented mice received $\sim 20 \mathrm{mg}$ of NM/day. After four weeks, the mice were sacrificed and their tumors were excised, weighed and processed for histology. The mean weight of mice at initiation of the study and termination of the study did not differ significantly between the groups.

Histology. Tissue samples were fixed in $10 \%$ buffered formalin. All tissues were embedded in paraffin and cut at 4-5 $\mu \mathrm{m}$. Sections were deparaffinized through xylene and graduated alcohol series to water and stained with hematoxylin and eosin (H\&E) for evaluation using a standard light microscope.

\section{In vitro studies}

Cell culture. Human neuronal epithelioma SK-N-MC cells (ATCC) were grown in MEM, supplemented with $10 \%$ fetal bovine serum, penicillin $(100 \mathrm{U} / \mathrm{ml})$ and streptomycin $(100 \mathrm{mg} / \mathrm{ml})$ in 24-well tissue culture plates (Costar, Cambridge, MA, USA). Cells were incubated with $1 \mathrm{ml}$ of media at $37^{\circ} \mathrm{C}$ in a tissue culture incubator equilibrated with $95 \%$ air and $5 \% \mathrm{CO}_{2}$. At near confluence, the cells were treated with the nutrient mixture, dissolved in media and tested at 0 , $10,50,100,500$ and $1,000 \mu \mathrm{g} / \mathrm{ml}$ in triplicate at each dose. Phorbol 12-myristate 13-acetate (PMA) (100 ng/ml) was added to the cells to induce MMP-9 secretion. The plates were then returned to the incubator.

MTT assay. Cell viability was evaluated by MTT assay, a colorimetric assay based on the ability of viable cells to reduce a soluble yellow tetrazolium salt [3-(4,5-dimethylthiazol-2-yl) 2,5-diphenyl tetrazolium bromide] (MTT) to a blue formazan crystal by mitochondrial succinate dehydrogenase activity of viable cells. This test is a good index of mitochondrial activity and thus of cell viability. After a 24-h incubation, the cells were washed with phosphate-buffered saline (PBS) and $500 \mu \mathrm{l}$ of MTT (\#M-2128; Sigma) $0.5 \mathrm{mg} / \mathrm{ml}$ in media was added to each well. After MTT addition $(0.5 \mathrm{mg} / \mathrm{ml})$, the plates were covered and returned to the $37^{\circ} \mathrm{C}$ incubator for $2 \mathrm{~h}$, the optimal time for formazan product formation. Following incubation, the supernatant was carefully removed from the wells, the formazan product was dissolved in $1 \mathrm{ml}$ DMSO, and absorbance was measured at $570 \mathrm{~nm}$ in the BioSpec 1601 Shimadzu spectrometer. The $\mathrm{OD}_{570}$ of the DMSO solution in each well was considered to be proportional to the number of cells. The $\mathrm{OD}_{570}$ of the control (treatment without supplement) was considered $100 \%$.

Gelatinase zymography. Gelatinase zymography was performed in $10 \%$ Novex Pre-Cast SDS polyacrylamide gel (Invitrogen) in the presence of $0.1 \%$ gelatin under non-reducing conditions. Culture media $(20 \mu \mathrm{l})$ were mixed with sample buffer and loaded for SDS-PAGE with Tris glycine SDS buffer as suggested by the manufacturer (Novex). Samples were not boiled before electrophoresis. Following electrophoresis the gels were washed twice in $2.5 \%$ Triton X-100 for $30 \mathrm{~min}$ at room temperature to remove SDS. The gels were then incubated at $37^{\circ} \mathrm{C}$ overnight in substrate buffer containing $50 \mathrm{mM}$ Tris- $\mathrm{HCl}$ and $10 \mathrm{mM} \mathrm{CaCl}_{2}$ at $\mathrm{pH} 8.0$ and stained with $0.5 \%$ Coomassie Blue R-250 in 50\% methanol and $10 \%$ glacial acetic acid for $30 \mathrm{~min}$ and destained. Upon renaturation of the enzyme, the gelatinases digest the gelatin in the gel and provide clear bands against an intensely stained background. Protein standards were run concurrently, and approximate molecular weights were determined by plotting the relative mobilities of known proteins.

Reverse zymography. TIMPs were analyzed by reverse zymography on $15 \%$ SDS gels containing serum-free conditioned medium from cells. After electrophoresis the gels were washed twice with $2.5 \%$ Triton $\mathrm{X}-100$ for $30 \mathrm{~min}$ at room temperature to remove SDS. The gels were then incubated at $37^{\circ} \mathrm{C}$ overnight in $50 \mathrm{mM}$ Tris- $\mathrm{HCl}$ and $10 \mathrm{mM} \mathrm{CaCl}_{2}$ at $\mathrm{pH} 7.6$ and stained with $0.5 \%$ Coomassie Blue R-25, destained and scanned.

Scanning of gelatinase and reverse zymograms. Gelatinase and reverse zymograms were scanned using CanoScan $9950 \mathrm{~F}$ Canon scanner at $300 \mathrm{dpi}$. The intensity of the bands was evaluated using the pixel-based densitometer program Un-Scan-It, version 5.1, 32-bit, by Silk Scientific, Inc. (Orem, UT, USA), at a resolution of 1 scanner unit (1/100 of an inch for an image that was scanned at $100 \mathrm{dpi}$ ). The pixel densitometer calculates the optical density of each pixel (values 0 to 255) using the darkly stained background of the gel as a pixel value of 0 . A logarithmic optical density scale was used since the optical density of films and gels is logarithmically proportional to the concentration. The pixel densitometer sums the optical density of each pixel to give a band's density. In all graphs, band densities were reported as percentages of the sums of all pixels in a given lane (treatment) of a gel.

Matrigel invasion. Invasion studies were conducted using Matrigel (Becton-Dickinson) inserts in 24-well plates. Suspended in medium, SK-N-MC cells were supplemented with nutrients, as specified in the design of the experiment and seeded on the insert in the well. Thus, both the medium on the insert and in the well contained the same supplements. The plates with the inserts were then incubated in a culture incubator equilibrated with $95 \%$ air and $5 \% \mathrm{CO}_{2}$ for $24 \mathrm{~h}$. After incubation, the media from the wells were withdrawn. The 


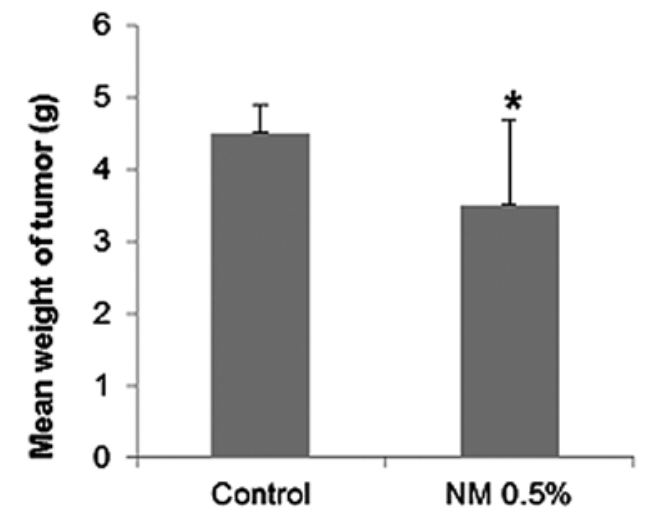

Figure 1. Effect of NM on the growth of human neuroblastoma SK-N-MC subcutaneous xenograft tumors in male nude mice. The comparative mean weights of tumors in the groups are indicated. NM inhibited the mean tumor weight by $22 \%(\mathrm{P}=0.04)$ with respect to the control group $\left({ }^{*} \mathrm{P}<0.05\right)$.

cells on the upper surface of the inserts were gently scrubbed away with cotton swabs. The cells that had penetrated the Matrigel membrane and migrated onto the lower surface of the Matrigel were stained with $H \& E$ and visually counted under a microscope.

Morphology and apoptosis. Morphology of cells cultured for $24 \mathrm{~h}$ in test concentrations of NM were evaluated by H\&E staining and observed and photographed by microscopy. At near confluence, SK-N-MC cells were challenged with NM dissolved in media at $0,50,100,250,500$ and $1,000 \mu \mathrm{g} / \mathrm{ml}$ and incubated for $24 \mathrm{~h}$. The cell culture was washed with PBS and treated with the caspase reagent as specified in the manufacturer's protocol (Molecular Probes Image-IT ${ }^{\mathrm{TM}}$ Live Green Poly Caspases Detection Kit 135104; Invitrogen). The cells were photographed under a fluorescence microscope and counted. Green-colored cells represented viable cells, while yellow-orange colored cells were early apoptotic and red, late apoptotic

Statistical analysis. Data are expressed as means $\pm \mathrm{SD}$, as indicated in the results, for the groups. Data were analyzed by independent sample t-test. Pearson's correlation coefficients were determined for toxicity and invasion correlations to NM concentration using MedCalc Software (Markakerke, Belgium).

\section{Results}

In vivo

Tumor growth. NM supplementation significantly inhibited neuroblastoma SK-N-MC xenograft tumor growth. The mean weight of tumors in the nude mice fed the $0.5 \% \mathrm{NM}$ supplement was inhibited by $22 \%(\mathrm{P}=0.04)$ in comparison to that of the control group of mice (Figs. 1 and 2).

Histopathology. Histologically the tumors from both groups were composed of necrotic, expansile, subcutaneous neoplastic masses consistent with neuroblastoma (Fig. 3).

\section{In vitro}

Cytotoxicity. NM exhibited no toxicity to human neuroblastoma SK-N-MC cells at low concentrations of NM, but cytotoxicity of $27 \%(\mathrm{P}=0.001)$ was evident at $500 \mu \mathrm{g} / \mathrm{ml} \mathrm{NM}$ and $36 \%$ $(\mathrm{P}=0.002)$ at $1,000 \mu \mathrm{g} / \mathrm{ml} \mathrm{NM}$ (Fig. 4).
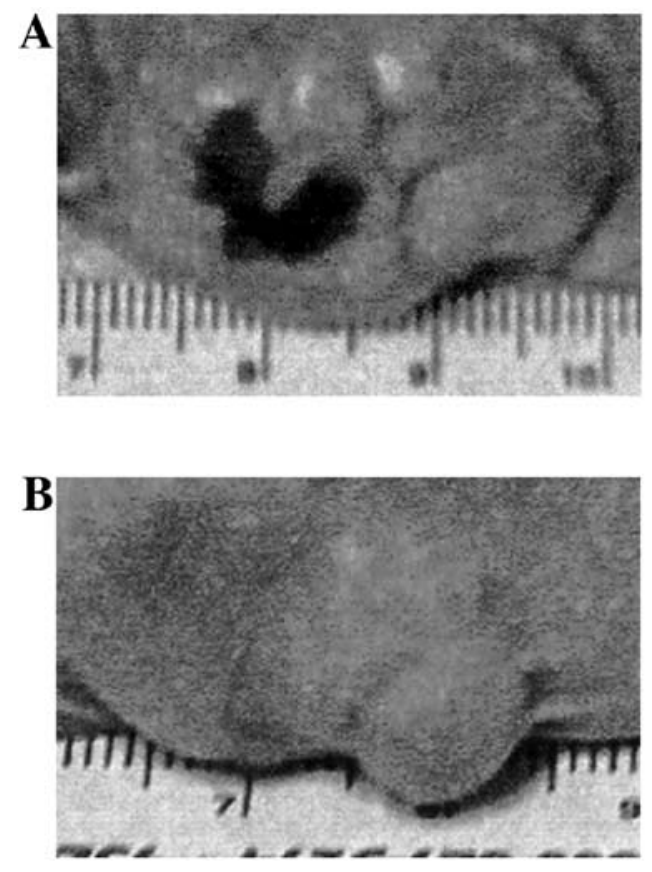

Figure 2. Effect of NM on the growth of human neuroblastoma SK-N-MC subcutaneous xenograft tumors in male nude mice. Representative images of gross tumors from (A) control and (B) $0.5 \%$ NM supplemented groups.

Gelatinase zymography. Zymography showed a faint band corresponding to MMP-2 secretion, and PMA (100 ng/ml)induced MMP-9 secretion. NM inhibited the secretion of both MMP-2 and -9 with total blockage at a concentration of $100 \mu \mathrm{g} / \mathrm{ml}$ (Fig. 5). MMP-2 secretion by normal SK-N-MC cells was inhibited by $50 \%$ by $50 \mu \mathrm{g} / \mathrm{ml} \mathrm{NM}$, and virtually blocked by NM 100-1,000 $\mu \mathrm{g} / \mathrm{ml}$ (linear trend $\mathrm{R}^{2}=0.756$ ). Secretion of MMP-2 by PMA-treated cells was inhibited by $73 \%$ at $50 \mu \mathrm{g} / \mathrm{ml} \mathrm{NM}$ and virtually blocked at $100-1,000 \mu \mathrm{g} / \mathrm{ml}$ $\mathrm{NM}$ (linear trend $\mathrm{R}^{2}=0.691$ ). MMP-9 secretion by PMA-treated cells was inhibited by $64 \%$ at $50 \mu \mathrm{g} / \mathrm{ml} \mathrm{NM}$ and virtually blocked at $100-1,000 \mu \mathrm{g} / \mathrm{ml} \mathrm{NM}$ (linear trend $\mathrm{R}^{2}=0.791$ ).

TIMP-2. Reverse zymography revealed upregulation of TIMP-2 activity following NM treatment of SK-N-MC cells in a dose-dependent manner, with minimum activity expressed at 50 and maximum activity at $1,000 \mu \mathrm{g} / \mathrm{ml} \mathrm{NM}$ (linear trend $\mathrm{R}^{2}=0.877$ ). Reverse zymogram and densitometry analysis are shown in Fig. 6.

Correlation of MMP-2 and TIMP-2. A negative correlation (correlation coefficient $\mathrm{r}=-0.8646$ ) was found between MMP-2 and TIMP-2 expression in the NM-treated SK-N-MC cells (Fig. 7).

Matrigel invasion. Notably, human neuroblastoma SK-N-MC cells were not invasive through Matrigel.

Cell morphology and apoptosis. Neuroblastoma cells exposed to various concentrations of NM indicated no morphological changes at concentrations $<500 \mu \mathrm{g} / \mathrm{ml}$ as detected by H\&E staining (Fig. 8). Using the Live Green Poly Caspases Detection kit, dose-dependent apoptosis of neuroblastoma cells was evident following NM challenge (Fig. 9). At $100 \mu \mathrm{g} / \mathrm{ml} \mathrm{NM,} \mathrm{67 \%} \mathrm{of} \mathrm{cells} \mathrm{were} \mathrm{viable,} 15 \%$ of cells were early apoptotic and $18 \%$ of cells were late apoptotic. At $500 \mu \mathrm{g} / \mathrm{ml} \mathrm{NM}, 50 \%$ of cells were viable, $15 \%$ of cells were early apoptotic, and $35 \%$ of cells were late apoptotic. At 

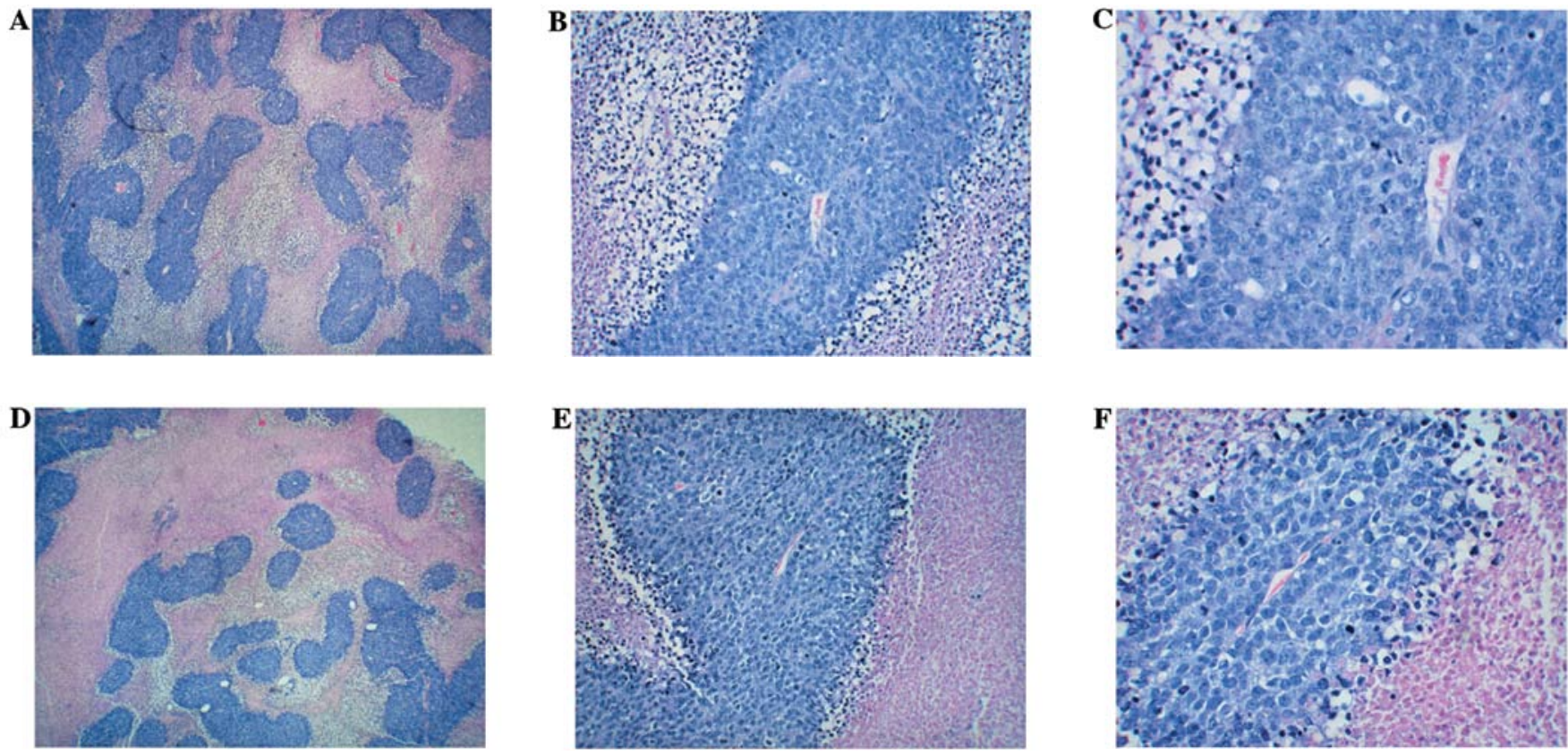

Figure 3. Histopathology of human neuroblastoma SK-N-MC subcutaneous xenograft tumors in the groups. Representative photomicrographs: (A) control, x40; (B) control, x 200; (C) control, x400; (D) NM 0.5\%, x40; (E) NM 0.5\%, x200; (F) NM 0.5\%, x400. Histologically, the tumors from both groups were composed of necrotic, expansile, subcutaneous neoplastic masses consistent with neuroblastoma.

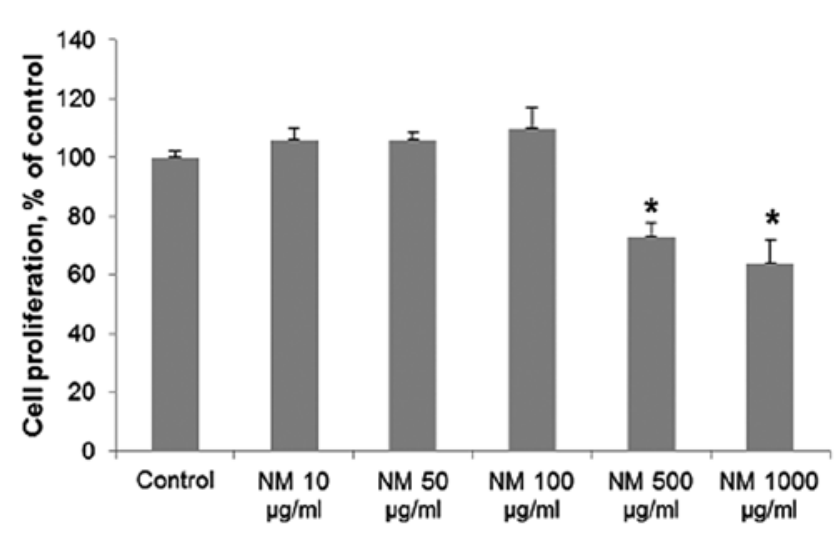

Figure 4. Effect of NM on the viability of neuroblastoma SK-N-MC cells at $24 \mathrm{~h}$ as determined by MTT assay. NM exhibited no toxicity to human neuroblastoma SK-N-MC cells at low concentrations of NM, but cytotoxicity of $27 \%(\mathrm{P}=0.001)$ was evident at $500 \mu \mathrm{g} / \mathrm{ml} \mathrm{NM}$ and $36 \%(\mathrm{P}=0.002)$ at $1,000 \mu \mathrm{g} / \mathrm{ml} \mathrm{NM}$.

$1,000 \mu \mathrm{g} / \mathrm{ml} \mathrm{NM}, 23 \%$ of cells were viable, $14 \%$ of cells were early apoptotic and $63 \%$ of cells were late apoptotic (Fig. 10).

\section{Discussion}

Dietary supplementation with $0.5 \%$ NM resulted in a $22 \%$ reduction in tumor growth in immune impaired (athymic) male nude mice after subcutaneous administration of $3 \times 10^{6}$ human neuroblastoma SK-N-MC cells. Results from the cellular proliferation and apoptosis studies support the in vivo results, as NM showed dose-dependent toxicity in SK-N-MC cells and induced apoptosis in a dose-dependent manner, with $36 \%$ inhibition of cell growth and apoptotic induction of $77 \%$ in cells exposed to $1,000 \mu \mathrm{g} / \mathrm{ml} \mathrm{NM}$.
Malignant neuroblastoma is a highly vascularized solid tumor that requires access to blood vessels for growth, invasion and metastasis, and angiogenesis plays an important role in determining tumor phenotype (10). High tumor vascularity is correlated with widely disseminated disease and poor histology and outcome in contrast to low tumor vascularity, which is associated with favorable prognosis, such as localized disease and favorable histology. Thus, researchers are focusing on targeting angiogenesis for the treatment of neuroblastoma (10). Ribatti et al (11) reviewed the progress in pre-clinical and clinical research of anti-angiogenic tumor therapy for neuroblastoma. Angiogeneis is mediated by multiple regulating factors, such as growth factors, adhesion molecules and matrix degrading enzymes. In a previous study, NM significantly $(\mathrm{P}<0.05)$ reduced $b F G F-i n d u c e d$ angiogenesis [utilizing a chorioallantoic membrane (CAM) assay] in chick embryos, as well as decreased human osteosarcoma U2OS cell expression of VEGF, angiopoietin-2, bFGF, PDGF and TGF $\beta-1$ (7).

Net matrix degradation and proteolysis depend on the critical local balance between MMPs and TIMP-2. Ara et al (5) reported that examination of tumor tissues of 25 neuroblastoma patients for levels of MMPs and TIMP-2 and correlation with stage of disease, revealed poor prognosis with elevated MMP-2 expression and significantly higher advanced stages of neuroblastoma with increased ratios of MMP-2/TIMP-2. In the present study, NM demonstrated dose-dependent inhibition of MMP-2 and -9 secretion by normal and PMA-treated cells with total blockage of both MMPs at $100 \mu \mathrm{g} / \mathrm{ml}$ NM. Furthermore, NM upregulated TIMP-2 activity in SK-N-MC cells in a dosedependent manner, with minimum activity expressed at 50 and maximum activity at $1,000 \mu \mathrm{g} / \mathrm{ml} \mathrm{NM}$. A negative correlation (correlation coefficient $\mathrm{r}=-0.8646$ ) was found between MMP-2 and TIMP-2 expression in the NM-treated SK-N-MC cells. 


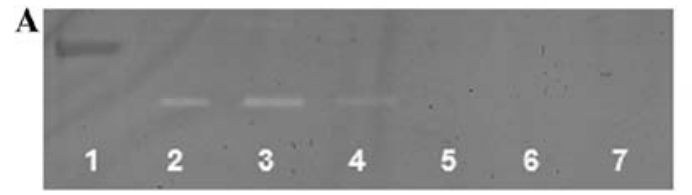

MMP-2

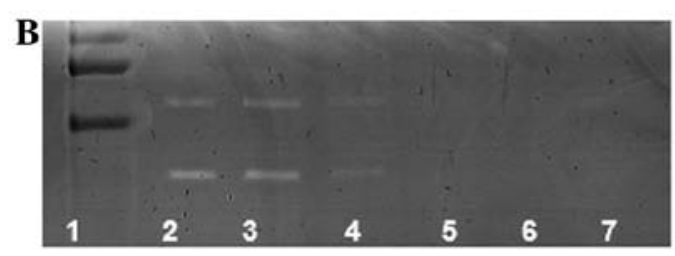

MMP-9

MMP-2
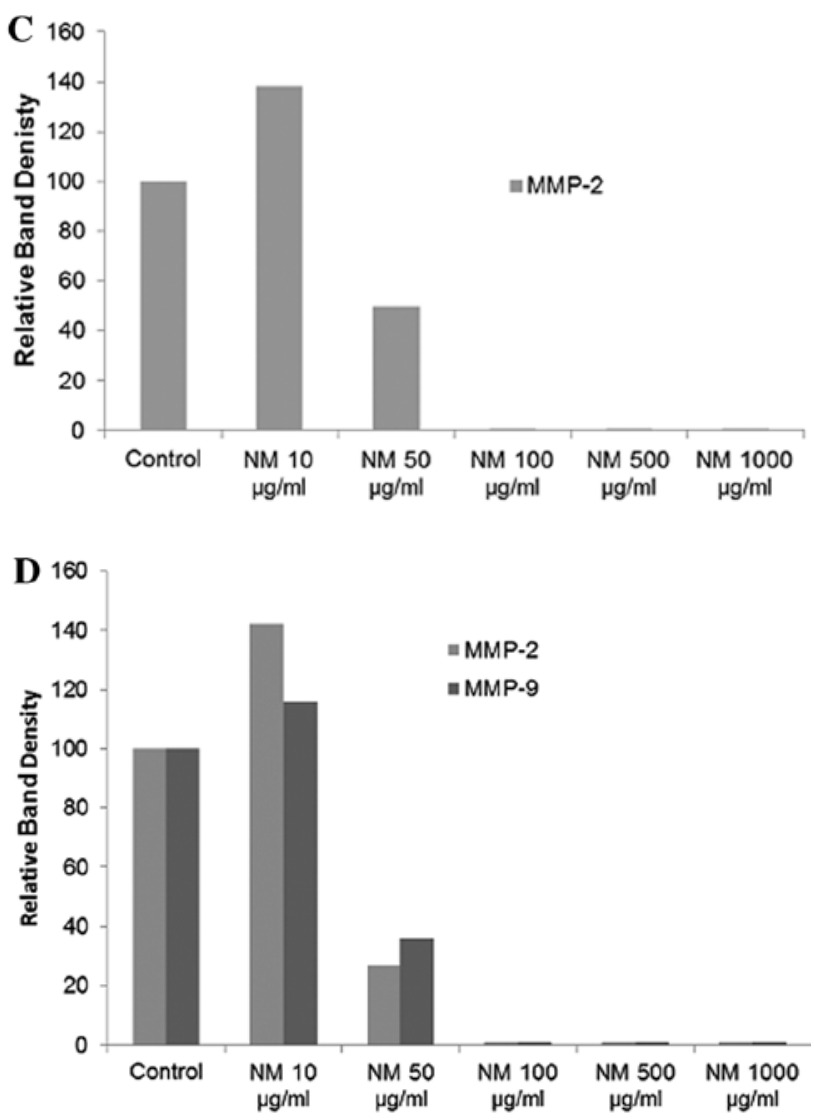

Figure 5. Effect of NM on SK-N-MC cell secretion of MMP-2 and MMP-9 by (A) normal cells and (B) PMA (100 ng/ml)-treated cells. Lane 1, markers; lane 2, control; lanes 3-7, NM 10,50, 100,500 and 1,000 $\mu \mathrm{g} / \mathrm{ml}$. Densitometry analysis of (C) uninduced SK-N-MC cells and (D) PMA-treated SK-N-MC cells. Zymography showed a faint band corresponding to MMP-2 secretion, and PMA (200 ng/ml)-induced MMP-9 secretion. NM inhibited the secretion of both MMP-2 and -9 with total blockage at $100 \mu \mathrm{g} / \mathrm{ml}$ concentration.

The ratio of MMP-2/TIMP-2 expression decreased significantly with increased NM dose: 11.9 at $50 \mu \mathrm{g} / \mathrm{ml} \mathrm{NM}, 1.9$ at $100 \mu \mathrm{g} / \mathrm{ml} \mathrm{NM}$ and 0 at $250-1,000 \mu \mathrm{g} / \mathrm{ml} \mathrm{NM}$.

NM was formulated by defining critical physiological targets in cancer progression and metastasis, such as ECM integrity and MMP activity. Adequate supplies of ascorbic acid and the amino acids lysine and proline ensure proper synthesis and hydroxylation of collagen fibers for optimal ECM structure. Manganese and copper are also essential for collagen formation. Lysine, a natural inhibitor of plasmin-induced proteolysis, plays an important role in ECM stability $(12,13)$. Green tea extract has been shown to modu-
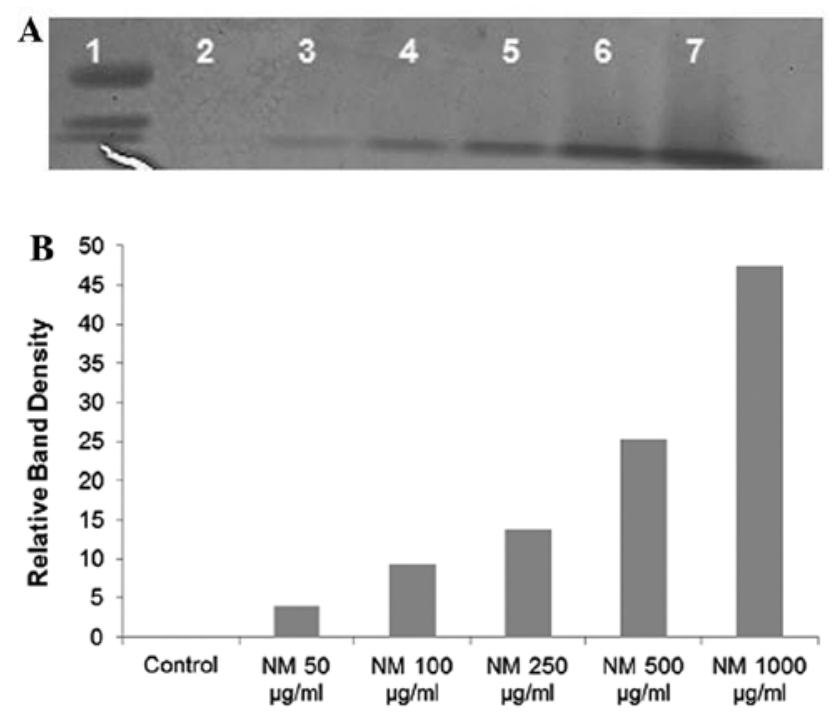

Figure 6. Effect of NM on SK-N-MC cell secretion of TIMP-2. (A) Reverse zymogram: lane 1, markers; lane 2, control; lanes 3-7, NM 10, 50, 100, 500 $1,000 \mu \mathrm{g} / \mathrm{ml}$ and (B) densitometry analysis. Reverse zymography revealed upregulation of TIMP-2 activity following NM treatment of SK-N-MC cells in a dose-dependent manner, with minimum activity expressed at 50 and maximum activity at $1,000 \mu \mathrm{g} / \mathrm{ml} \mathrm{NM}$ (linear trend $\mathrm{R}^{2}=0.877$ ).

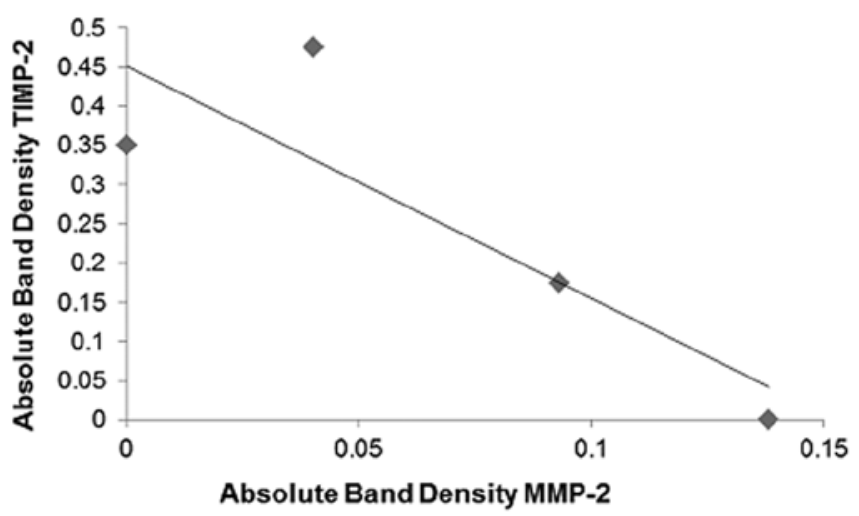

Figure 7. Correlation between secretion of MMP-2 and TIMPs by NM-treated SK-N-MC cells. A negative correlation (correlation coefficient $\mathrm{r}=-0.8646$ ) was found between MMP-2 and TIMP-2 expression in NM-treated SK-N-MC cells.

late cancer cell growth, metastasis, angiogenesis, and other aspects of cancer progression (14-18). N-acetyl cysteine has been shown to modulate MMP-9 and invasive activities of tumor cells $(19,20)$. Selenium has been shown to inhibit MMP secretion, tumor invasion, and migration of endothelial cells through ECM (21). Ascorbic acid demonstrates cytotoxic and antimetastatic actions on neuroblastoma and other malignant cell lines (22-27), and cancer patients have been found to have low levels of ascorbic acid $(28,29)$. Low levels of arginine, a precursor of nitric oxide (NO), can limit the production of NO, which has been shown to predominantly act as an inducer of apoptosis (30).

In conclusion, current treatment methods for neuroblastoma are generally ineffective and particularly toxic to these patients. Thus, there is a need for the development of effective therapeutic agents for these cancers with minimal toxicity. 

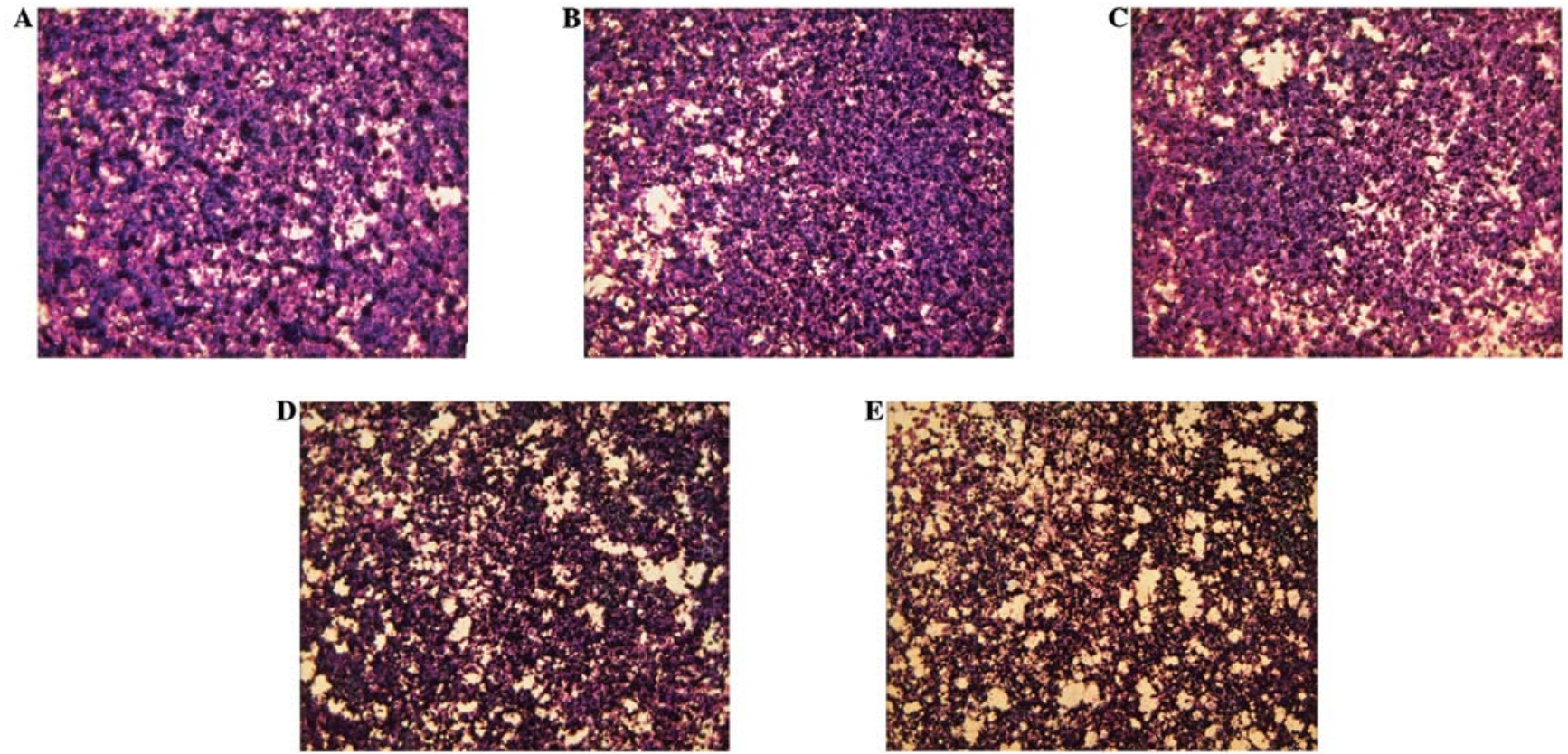

Figure 8. Effect of NM on the morphology of SK-N-MC cells as detected by H\&E staining. Neuroblastoma cells exposed to various concentrations of NM indicated no morphological changes at concentrations $<500 \mu \mathrm{g} / \mathrm{ml}$. (A) Control, (B) NM $50 \mu \mathrm{g} / \mathrm{ml}$, (C) NM $100 \mu \mathrm{g} / \mathrm{ml}$, (D) NM $500 \mu \mathrm{g} / \mathrm{ml}$ and (E) NM 1,000 $\mu \mathrm{g} / \mathrm{ml}$.
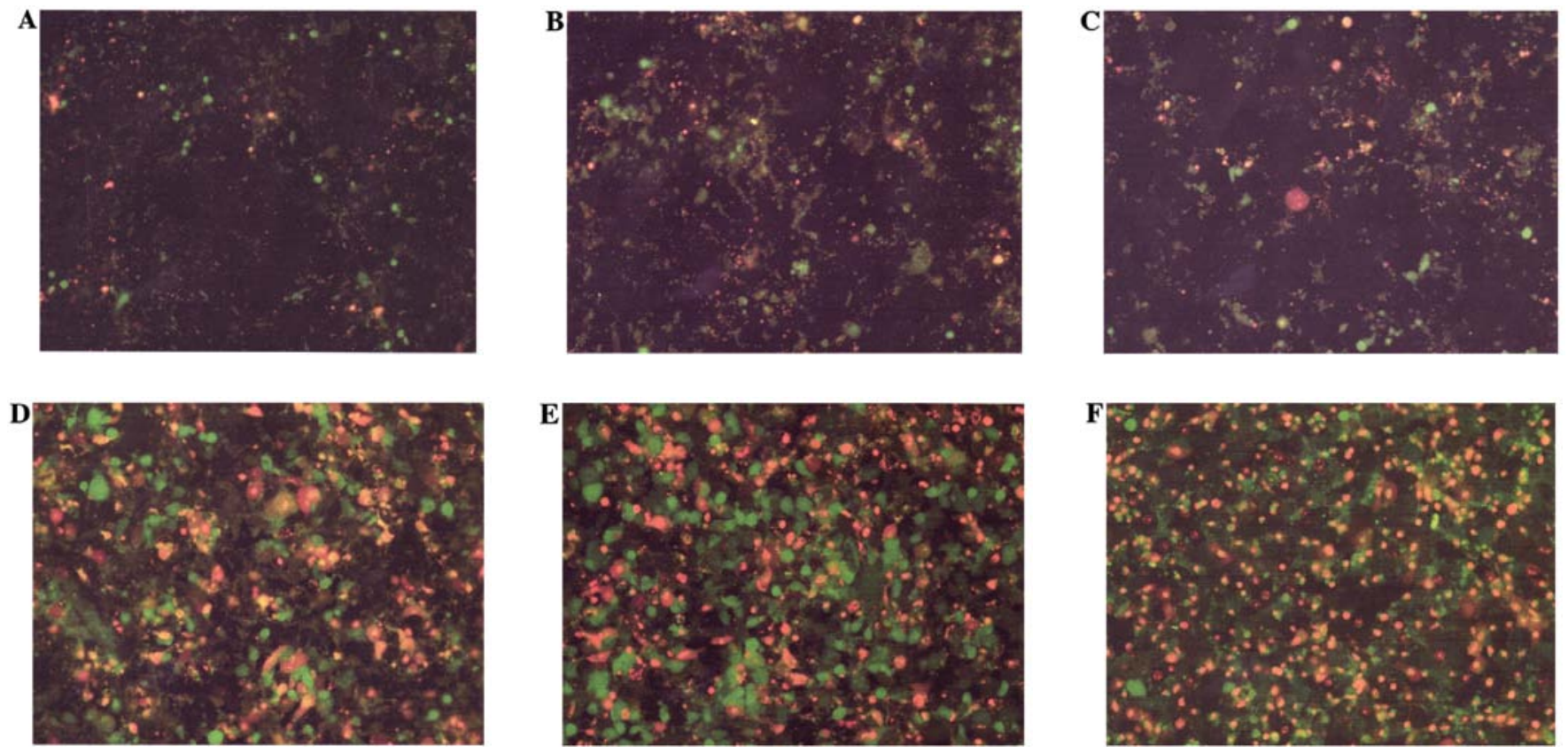

Figure 9. Effect of NM on the apoptosis of SK-N-MC cells. Dose-dependent apoptosis of neuroblastoma cells was evident following NM challenge. (A) Control, (B) NM $50 \mu \mathrm{g} / \mathrm{ml}$, (C) NM $100 \mu \mathrm{g} / \mathrm{ml}$, (D) NM $250 \mu \mathrm{g} / \mathrm{ml}$, (E) NM $500 \mu \mathrm{g} / \mathrm{ml}$ and (F) NM $1000 \mu \mathrm{g} / \mathrm{ml}$.

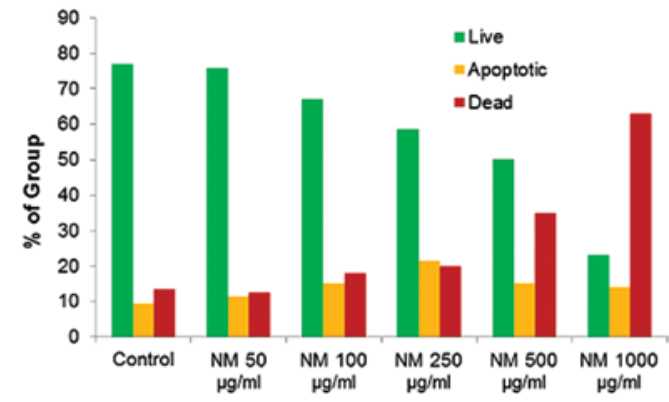

Figure 10. Effect of NM on the apoptosis of SK-N-MC cells; statistical analysis.
Our studies demonstrated that NM significantly inhibited the growth of xenograft tumors derived from the neuroblastoma cell line SK-N-MC in vivo and significantly inhibited cell proliferation and induced apoptosis in vitro. In addition, invasive parameters, such as MMP-2 and -9 secretion, in the SK-N-MC cell line were significantly inhibited by NM in vitro, while TIMP-2 was enhanced. These findings suggest the potential of NM for the treatment of neuroblastoma. Furthermore, in contrast to the toxic side effects of chemotherapy, the nutrient mixture was shown to be a safe therapeutic agent. In a previous in vivo study addressing safety issues, we found that 
gavaging adult female ODS rats (weighing 250-300 g) with the nutrient mixture (at 30, 90 or $150 \mathrm{mg} /$ day for 7 days), had neither adverse effects on vital organs (heart, liver and kidney) nor on associated functional serum enzymes, indicating that this mixture is safe to use even at high doses, which far exceed the normal equivalent dosage of the nutrient (31).

\section{Acknowledgements}

The research study was funded by Dr. Rath Health Foundation (Santa Clara, CA, USA), a non-profit organization. Consulting pathologist Alexander de Paoli of IDEXX Reference Laboratories provided the histopathology slides of the neuroblastoma SK-N-MC tumors.

\section{References}

1. American Cancer Society: Neuroblastoma: What are the key statistics about neuroblastoma? http://www.cancer.org/Cancer/ Neuroblastoma/DetailedGuide/neuroblastoma-key-statistics. Accessed Dec 6, 2012.

2. Reynolds CP and Seeger RC: Neuroblastoma. In: Cancer Treatment. Haskell CM (ed). W.B. Saunders, Philadelphia, PA, pp860-871, 1994.

3. Matthay KK, Villablanca JG, Seeger RC, Stram DO, Harris RE, Ramsay NK, Swift P, Shimada H, Black CT, Brodeur GM, Gerbing RB and Reynolds CP: Treatment of high-risk neuroblastoma with intensive chemotherapy, radiotherapy, autologous bone marrow transplantation and 13-cis-retinoic acid. Children's Cancer Group. N Engl J Med 341: 1165-1173, 1999.

4. Roy Choudhury S, Karmakar S, Banik NL and Ray SK Targeting angiogenesis for controlling neuroblastoma. J Oncol 2012: 782020, 2012. doi: 10.1155/2012/82020.

5. Ara T, Kusafuka T, Inoue M, Kuroda S, Fukuzawa M and Okada A: Determination of imbalance between MMP-2 and TIMP-2 in human neuroblastoma by reverse-transcription polymerase chain reaction and its correlation with tumor progression. J Pediatr Surg 35: 432-437, 2000.

6. Sugiura Y, Shimada H, Seeger RC, Laug WE and DeClerck YA: Matrix metalloproteinases-2 and-9 are expressed in human neuroblastoma: contribution of stromal cells to their production and correlation with metastasis. Cancer Res 58: 2209-2216, 1998.

7. Roomi MW, Roomi N, Ivanov V, Kalinovsky T, Niedzwiecki A and Rath M: Inhibitory effect of a mixture containing ascorbic acid, lysine, proline and green tea extract on critical parameters in angiogenesis. Oncol Rep 14: 807-815, 2005.

8. Roomi MW, Roomi N, Ivanov V, Kalinovsky T, Niedzwiecki A and Rath M: Inhibition of pulmonary metastasis of melanoma $\mathrm{B} 16 \mathrm{FO}$ cells in C57BL/6 mice by a nutrient mixture consisting of ascorbic acid, lysine, proline, arginine, and green tea extract. Exp Lung Res 32: 517-530, 2006.

9. Niedzwiecki A, Roomi MW, Kalinovsky T and Rath M: Micronutrient synergy - a new tool in effective control of metastasis and other key mechanisms of cancer. Cancer Metastasis Rev 29: 529-542, 2010.

10. Ribatti D, Marimpietri D, Pastorino F, Brignole C, Nico B, Vacca A and Ponzoni M: Angiogenesis in neuroblastoma. Ann NY Acad Sci 1028: 133-142, 2004.

11. Ribatti D, Vacca A, Nico B, De Falco G, Montaldo GP and Pnzoni M: Angiogenesis and anti-angiogenesis in neuroblastoma. Eur J Cancer 38: 750-757, 2002.

12. Rath $M$ and Pauling L: Plasmin-induced proteolysis and the role of apoprotein(a), lysine and synthetic analogs. J Orthomolecular Med 7: 17-23, 1992.
13. Sun Z, Chen YH, Wang P, Zhang J, Gurewich V, Zhang P and Liu JN: The blockage of high-affinity lysine binding sites of plasminogen by EACA significantly inhibits prourokinase-induced plasminogen activation. Biochem Biophys Acta 1596: 182-192, 2002.

14. Valcic S, Timmermann BN, Alberts DS, Wachter GA, Krutzsch M, Wymer J and Guillen JM: Inhibitory effect of six green tea catechins and caffeine on the growth of four selected human tumor cell lines. Anticancer Drugs 7: 461-468, 1996.

15. Mukhtar H and Ahmad N: Tea polyphenols: prevention of cancer and optimizing health. Am J Clin Nutr 71 (Suppl 6): S1698-S1704, 2000.

16. Yang GY, Liao J, Kim K, Yurtow EJ and Yang CS: Inhibition of growth and induction of apoptosis in human cancer cell lines by tea polyphenols. Carcinogenesis 19: 611-616, 1998.

17. Taniguchi S, Fujiki H, Kobayashi H, Go H, Miyado K, Sadano H and Shimokawa R: Effect of (-) epigallocatechin gallate, the main constituent of green tea, on lung metastasis with mouse B16 melanoma cell lines. Cancer Lett 65: 51-54, 1992.

18. Hara Y: Green Tea: Health Benefits and Applications. Marcel Dekker, Inc., New York, Basel, 2001.

19. Kawakami S, Kageyama Y, Fujii Y, Kihara K and Oshima H: Inhibitory effects of N-acetyl cysteine on invasion and MMP-9 production of T24 human bladder cancer cells. Anticancer Res 21: 213-219, 2001.

20. Morini M, Cai T, Aluigi MG, Noonan DM, Masiello L, De Floro S, D'Agostinin F, Albini A and Fassima G: The role of the thiol $\mathrm{N}$-acetyl cysteine in the prevention of tumor invasion and angiogenesis. Int J Biol Markers 14: 268-271, 1999.

21. Yoon SO, Kim MM and Chung AS: Inhibitory effects of selenite on invasion of HT1080 tumor cells. J Biol Chem 276: 20085-20092, 2001.

22. Carosio R, Zuccari G, Orienti I, Mangraviti S and Montaldo PG: Sodium ascorbate induces apoptosis in neuroblastoma cell lines by interfering with iron uptake. Mol Cancer 6: 55, 2007.

23. Maramag C, Menon M, Balaji KC, Reddy PG and Laxmanan S: Effect of vitamin $C$ on prostate cancer cells in vitro: effect on cell number, viability and DNA synthesis. Prostate 32: 188-195, 1997.

24. Naidu KA, Karl RC, Naidu KA and Coppola D: Antiproliferative and proapoptotic effect of ascorbyl stearate in human pancreatic cancer cells: association with decreased expression of insulinlike growth factor 1 receptor. Dig Dis Sci 48: 230-237, 2003.

25. Koh WS, Lee SJ, Lee H, Park C, Park MH, Kim WS, Yoon SS, Park K, Hong SI, Chung MH and Park CH: Differential effects and transport kinetics of ascorbate derivatives in leukemic cell lines. Anticancer Res 18: 2487-2493, 1998.

26. Chen Q, Espey MG, Krishna MC, Mitchell JB, Corpe CP, Buettner GR, Shacter E and Levine M: Pharmacologic ascorbic acid concentrations selectively kill cancer cells: action as a pro-drug to deliver hydrogen peroxide to tissues. Proc Natl Acad Sci USA 102: 13604-13609, 2005.

27. Kurbacher CM, Wagner U, Kolster B, Andreotti PE, Krebs D and Bruckner HW: Ascorbic acid (vitamin C) improves the antineoplastic activity of doxorubicin, cisplatin and paclitaxel in human breast carcinoma cells in vitro. Cancer Lett 103: 183-189, 1996.

28. Anthony HM and Schorah CJ: Severe hypovitaminosis C in lungcancer patients: the utilization of vitamin $\mathrm{C}$ in surgical repair and lymphocyte-related host resistance. Br J Cancer 46: 354-367, 1982.

29. Nunez C, Ortiz de Apodaca Y and Ruiz A: Ascorbic acid in the plasma and blood cells of women with breast cancer. The effect of consumption of food with an elevated content of this vitamin. Nutr Hosp 10: 368-372, 1995 (In Spanish).

30. Cooke JP and Dzau VJ: Nitric oxide synthase: role in the genesis of vascular disease. Annu Rev Med 48: 489-509, 1997.

31. Roomi MW, Ivanov V, Netke SP, Niedzwiecki A and Rath M: Serum markers of the liver, heart, and kidney and lipid profile and histopathology in ODS rats treated with nutrient synergy. J Am Coll Nutr 22: 477, 2003. 